Instructions for authors, subscriptions and further details:

http://ijep.hipatiapress.com

\title{
The Potential Role of Perceived Support for Reduction of Special Education Teachers' Burnout
}

Viviana Langher ${ }^{1}$, Andrea Caputo ${ }^{1}$, Maria Elisabetta Ricci ${ }^{1}$

1) Sapienza University of Rome, Italy

Date of publication: June $24^{\text {th }}, 2017$

Edition period: June 2017 - October 2017

To cite this article: Langher, V., Caputo, A., \& Ricci, M.E. (2017). The potential role of perceived support for reduction of special education teachers' burnout. International Journal of Educational Psychology, 6(2), 120-147. doi: 10.17583/ijep.2017.2126

To link this article: http://dx.doi.org/10.17583/ijep.2017.2126

\section{PLEASE SCROLL DOWN FOR ARTICLE}

The terms and conditions of use are related to the Open Journal System and to Creative Commons Attribution License (CC-BY). 
IJEP - International Journal of Educational Psychology, Vol. 6 No. 2 June 2017 pp. 120-147

\section{The Potential Role of Perceived Support for Reduction of Special Education Teachers' Burnout}

Viviana Langher, Andrea Caputo, Maria Elisabetta Ricci

Sapienza University of Rome

\section{Abstract}

Teacher burnout is conceived as a general concern in special education because of the emotionally demanding work context. This study explored the potential role of perceived support for reduction of burnout in a sample of 276 special education teachers working in lower $(n=130)$ and higher $(n=146)$ secondary schools. Participants completed the Maslach Burnout Inventory - Educators Survey (MBIES) and a scale on the perceived collaboration and support from general education teachers. To explore the association between perceived support and each burnout measure considered (emotional exhaustion, depersonalisation, and personal accomplishment), correlation analyses were performed. Then, in order to check the robustness of our empirical findings, multilevel regression models (at teacherschool-administrative area level) were used controlling for several variables (teacher socio-demographic characteristics, teacher training and professional background, inclusive teaching practice and school context). Results suggest the potential role of perceived support in reducing emotional exhaustion and improving personal accomplishment in all the models considered. Instead, the relationship between perceived support and depersonalisation seems to be quite controversial, moreover when adding controls related to teacher's training and professional background.

Keywords: teacher burnout, special education, perceived support, inclusive teaching, multilevel regression models.

2017 Hipatia Press

ISSN: 2014-3591

DOI: $10.17583 /$ ijep.2017.2126

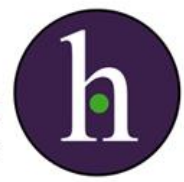


IJEP - International Journal of Educational Psychology, Vol. 6 No. 2 June 2017 pp. 120-147

\section{El Papel Potencial del Apoyo Percibido en la Reducción del 'Burnout' del Profesorado de Educación Especial}

Viviana Langher, Andrea Caputo, Maria Elisabetta Ricci Sapienza University of Rome

\section{Resumen}

El 'burnout' del profesorado se concibe como una preocupación general en la educación especial debido a un contexto de trabajo emocionalmente demandante. Este estudio exploró el papel potencial del apoyo percibido en la reducción del 'burnout' en una muestra de 276 maestros de educación especial que trabajaban en escuelas secundarias e nivel más bajo $(\mathrm{n}=130)$ y de nivel más alto $(\mathrm{n}=146)$. Los participantes completaron el Maslach Burnout Inventory - Educators Survey (MBIES) y una escala sobre el apoyo y la colaboración percibidas por parte de profesorado generalista. Para examinar la asociación entre apoyo percibido y cada medida de 'burnout' considerada (cansancio emocional, despersonalización y logro personal) se llevaron a cabo análisis de correlación. Posteriormente, para comprobar la solidez de los resultados empíricos se usaron modelos de regresión multinivel (al nivel de profesor-escuela-área administrativa) controlando varias variables (las características socio-demográficas del profesorado, la formación del profesorado y el bagaje profesional, enseñanza inclusiva y contexto escolar). Los resultados sugieren el papel potencial del apoyo percibido en la reducción del cansancio emocional y en la mejora del logro personal en todos los modelos considerados. Sin embargo, la relación entre el apoyo percibido y la despersonalización parece ser controvertida, además cuando se añaden controles relacionados con la formación del profesorado y al bagaje profesional.

Palabras clave: 'Burnout' del profesorado, educación especial, apoyo percibido, enseñanza inclusiva, modelos de regresión multinivel. 


\section{Langher, Caputo, Ricci - The Role of Perceived Support}

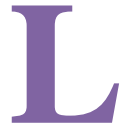

iterature highlights a high rate of professional turnover in special education mostly due to the role of job-related stress (Cancio, Albrecht, \& Johns, 2013; Hinds, Jones, Gau, Forrester, \& Biglan, 2015; Zabel \& Zabel, 2002). Honawar (2006) states the national attrition rate of special education teachers at a high of $13.5 \%$; besides, almost $1 / 3$ of new special education teachers leave the profession after three years in the field (Dillon, 2007). Indeed, special education teachers are more likely to face challenging situations than the general teachers, such as custodial and managerial tasks, a perceived lack of job success, programme structure, and work overload (Friedman, 2000; Sari, 2004). Indeed, many diverse challenges and expectations, complex demands, and stress-inducing factors are endemic to this occupation, because students with special education needs often require constant support (Stoesz et al., 2016). Special education teachers tend to experience different challenging students' behaviors, such as being more active and easily distractible than other students, requesting greater attention to achieve educational goals, and expressing an aggressive/hostile conduct (Pepe \& Addimando, 2013). In addition, special education teachers have to cope with paradoxes and contradictions, because experiencing failure and acting as an attempt without a guarantee of success are distinctive characteristics of their occupational reality (Lindmeier, 2013). Therefore, their feeling of uncertainty in educational action and interaction is particularly pronounced, thus resulting in high stress and significant adverse consequences (Norwich, 2013). About two out of three teachers who leave the profession state as main reasons too much paperwork to be completed, lack of administrative support, not enough supplies, too many students and scarce collaboration with colleagues (Futernick, 2007; Kaff, 2004; Prather-Jones, 2011). Moreover, pressure from parents can be meaningfully intense, due to the complex and confusing emotional states parents may go through when dealing with physical and psychological health of their children (Kourkoutas, Langher, Vitalaki, \& Ricci, 2015). They can have unrealistic expectations or, on the contrary, they can underestimate the good results of their children at school (Langher, Caputo, Ajdinski, Ricci, \& Karovska, 2015). In the Italian context this problem is particularly relevant because of the institutional regulatory framework which requires mandatory inclusive practice for students with 
special education needs in all school grades. However, as revealed by recent data provided by the National Institute of Statistics (ISTAT, 2014) about the inclusion of students with disabilities, the lack of organisational and structural conditions of Italian schools does not allow the effective promotion of inclusive education, particularly in the current spending review period characterised by massive financial cuts in education. Indeed, the number of special education teachers is insufficient compared to the increasing population of students with disabilities (ISTAT, 2014). In addition, there is a lack of continuity of plans and actions due to administrative changes ${ }^{1}$ : most of students with a disability $(44.1 \%$ in primary school and $39.8 \%$ in lower secondary school) have their special education teachers changed from the previous school year (ISTAT, 2014). In the Italian education system, therefore, special education teachers seem to be caught in the grips of this critical situation: on the one hand, they are overloaded with high-performance expectations; on the other hand, they are considered as responsible, whether right or wrong, for the failure of dysfunctional inclusive processes. As suggested by Acanfora (2002), this may lead to teacher burnout, characterised by feelings of low personal accomplishment, reduced professional self-efficacy, job disengagement, poor interactions and attitudes towards students and colleagues, especially in those schools where there is a significant gap between high-performance expectations and scarce organisational, structural and relational conditions of work context.

In this regard, support from the general education teachers in a school is conceived as a key-factor which allows special education teachers to feel as though they are part of the school environment and to experience greater personal accomplishment (Billingsley, Carlson, \& Klein, 2002; Gersten, Keating, Yovanoff, \& Harniss, 2001), acceptance, and participation (Platsidou \& Agaliotis, 2008). On the contrary, without support, many special education teachers tend to feel isolated and lonely (Schlichte, Yssel, $\&$ Merbler, 2005) and to be affected by higher levels of burnout (Hakanen, Bakker, \& Schaufeli, 2006; Leung \& Lee, 2006; Schaufeli \& Bakker, 2004; Talmor, Reiter, \& Feigin, 2005). Indeed, special education teachers are more positive about inclusion when they are provided with high quality support (Al-Shammari, 2006; Avramidis \& Norwich, 2002). They can benefit of 


\section{Langher, Caputo, Ricci-The Role of Perceived Support}

sharing with mainstream teachers the decisions about the didactic for children with special education needs, ameliorating the quality of their own instruction. This can positively affect the general quality of the didactic in the class, as well as the quality of the relationship between teachers and students, and among students, thus reducing the risk of isolation in class for children with special education needs. In this sense, inclusion could become a successful possibility for more students when there are support staff and other resources involved (Langher, Caputo, Ajdinski, Ricci \& Karovska, 2015; Langher et al., 2015; Langher, Ricci, Propersi, Glumbic \& Caputo, 2016).

This suggests the importance of the subjective dimension because, despite the limitations and inadequateness of organisational and structural conditions, the perception of being supported can have a significant role in reducing the negative effects of lacking school resources, otherwise the quality of inclusive processes at school can decline (Reversi, Langher, Crisafulli, \& Ferri, 2007; Langher, Ricci, Reversi, \& Citarelli, 2010). In other words, subjective perception can be related to collusive processes (Carli \& Paniccia, 2003), in terms of emotional and symbolic dimensions through which teachers represent themselves and relationships with colleagues within their work context (Langher, Caputo, Ajdinski, Ricci, \& Karovska, 2015; Langher, Caputo, Ricci, \& Ajdinski, 2104). Regardless the amount of real received support, subjectively perceived support can thus act as a potential factor for reducing and regulating situations of potential teacher burnout.

\section{Aim of the Study}

The aim of this study is to explore the potential role of perceived support for reducing potential burnout in special education teachers coming from secondary school. In more detail, it aims at assessing the association between perceived support and collaboration with regular teachers and burnout dimensions (i.e. emotional exhaustion, depersonalisation, and personal accomplishment), taking into account special education teachers' environments. Indeed, special education teachers are nested within schools, which are in turn grouped within neighbourhoods or territorial areas, and so 
some context-related effects might exist. The relationship between perceived support (as independent variable) and burnout (as dependent variable) is also controlled for several variables, related to four main domains (teacher sociodemographic characteristics, teacher training and professional background, inclusive teaching practice and school context) in order to test whether perceived support can maintain a significant predictive validity in reducing the different burnout measures.

\section{Method}

\section{Participants and Procedure}

The sample of this study comprised 276 special education teachers working in lower $(n=130)$ and higher $(n=146)$ secondary schools in the city of Rome. The sample was composed of 224 female (81.2\%) and 52 male (18.8\%) teachers, consistently with general trends on teachers' gender distribution in the Italian context (OECD, 2008). They were grouped in two main age classes - respectively 30-44 (51.4\%) and 45-62 (48.6\%) years old - and their years of tenure ranged from 1 to 35 (Mean=17.64; $\mathrm{SD}=7.99$ ).

A two-step sampling procedure was used. In the first step, a group of 107 secondary schools - both at lower $(n=56)$ and higher $(n=51)$ levels - were selected by a stratified random sampling based on the different administrative areas where schools were located. These areas are well distributed along three levels of socio-economic disadvantage (low, medium, high), according to data provided by the Italian Center for Social Studies and Policies (CENSIS). In the second step, a sample of special education teachers was recruited from these schools by using convenience sampling, which included those available to participate in the study (on average, about three teachers by school). The special education teachers were contacted after obtaining permission from the principles of the selected schools. The teachers were explained the general aim of the study, i.e. analysing the subjective perception of support at work and its role in contrasting burnout, and were asked to fill in a form for the informed consent. 


\section{Langher, Caputo, Ricci - The Role of Perceived Support}

\section{Instruments}

The perceived Collaboration and Support for Inclusive Teaching (CSIT) Scale. The CSIT scale (Caputo \& Langher, 2015) is composed of 12 items. Items scored on a 5-point Likert-type scale, ranging from 0 (never) to 4 (always) and evaluates the special education teachers' perception of several sources supporting their inclusive role, such as informal exchange and help provided by their general education colleagues (e.g., "When asked by me, my general education colleagues provide me with suggestions on how to behave with students with a disability they already know"), collaboration with them for co-planning instruction within the class (e.g., "During my class work, I collaborate with general education teachers in training activities regarding the whole class"), school and staff efforts for inclusion (e.g., "In staff meetings, the inclusion of students with a disability is favored by promotion, coordination and evaluation of pedagogical/didactic options addressed to them"), shared attitude toward disability and relevance attributed to inclusion (e.g., "General education teachers propose extra education whose planning meets the needs of students with a disability"). Good reliability $(\alpha=88)$ and face, construct, convergent and discriminant evidences of validity, including the association with teacher burnout, were established in previous research (Caputo \& Langher, 2015). Cronbach's alpha for the present sample is 0.876 .

Maslach Burnout Inventory, Educators Survey (MBI-ES). The questionnaire is used to assess teacher burnout (Maslach \& Jackson, 1986). It is composed of 22 items scored on a 7-point Likert-type scale, ranging from 0 (never) to 6 (everyday). It specifically measures three different burnout dimensions: Emotional Exhaustion (e.g., "I feel exhausted by my work"), Depersonalisation (e.g., "I'm afraid that this job is making me uncaring"), and Personal Accomplishment (e.g., "I look after my students' problems very effectively"). Emotional Exhaustion is characterised by psychological depletion caused by the constant demands of caring for others. This factor can include physiological illness, chronic fatigue, and decreased stress resistance. Teachers exhibit emotional exhaustion when they feel they can no longer extend themselves to students as they as they once did (Evers, Brouwers, \& Tomic, 2002; Maslach \& Jackson, 1986). Depersonalisation refers to negative disassociation, indifference to students as individuals, and 
a detached attitude toward individual student needs (Maslach \& Jackson, 1986). Satisfaction with Personal Accomplishment, a third indicator of teacher burnout, is evidenced by self-evaluation relative to job performance and expectations of future goal attainment. The Italian adaptation of MBI for educators (Sirigatti \& Stefanile, 1993) showed satisfactory internal consistency (.86 for Emotional Exhaustion, .63 for Depersonalisation and .71 for Personal Accomplishment) and was correlated with other measures such as anxiety, depression, somatic symptoms, hostility and job perceptions. Cronbach's alpha for the present sample is .77 for Emotional Exhaustion, .61 for Depersonalisation and .65 for Personal Accomplishment.

\section{Statistical Procedures}

To explore the association between perceived support and each burnout measure considered (i.e. emotional exhaustion, depersonalisation, and personal accomplishment), correlation analyses were performed.

Then, given the nested structure of data, multilevel regression analysis (three level random intercept: teacher-school-administrative area) was performed to predict each burnout measure as dependent variables, based on perceived support as explicative/independent variable. Because teachers who work in the same school or administrative area share the same environment and tend to be more alike than are teachers in different schools/administrative areas, their observations cannot be considered as independent. Therefore, multilevel modelling allows us to correctly estimate the relative variation in burnout based on perceived support, also considering the potential effect of clustering. Multilevel models recognize the existence of such data hierarchies by allowing for residual components at each level in the hierarchy (Hox, 2002). For example, a three-level model that allows for grouping of teacher measures within schools, nested within administrative areas, would include residuals at the teacher, school and administrative area level. Thus the residual variance is partitioned into a between school/administrative area component (the variance of the school/administrative area-level residuals) and a withinschool/administrative area component (the variance of the teacher-level residuals). The school/administrative area residuals represent unobserved school/administrative area characteristics that affect teacher measures. These 


\section{Langher, Caputo, Ricci - The Role of Perceived Support}

unobserved variables lead to correlation between outcomes for teachers from the same school/administrative area.

To check the robustness of our empirical findings and to test whether perceived support could maintain a significant predictive validity in reducing the different burnout measures after controlling for several variables, we defined five multilevel regression models progressively including some independent variables (covariates) to cleanse the association between special education teachers' perceived support and burnout measures of its spurious elements.

In order to define different multilevel regression models, Bronfenbrenner's (1977) Ecological Model was used as an organizational framework to order the variables associated with teacher burnout from proximal (e.g., teacher characteristics) to distal (e.g., external context). This model was used by both Brownell and Smith (1993) and by Brunsting, Sreckovic and Lane (2014) providing a synthesis of research on special education teacher burnout from 1979 to 2013. Studies are synthesized by the variables associated with burnout, beginning with the most proximal to the most distal (individual, classroom and school factors).

Model 1. It does not include any additional control.

Model 2. It includes some variables to control for teachers' sociodemographic characteristics: a dummy for gender and a dummy for age class, respectively 30-44 and 45-62 years old.

Model 3. In addition to model 2, it includes a set of control variables referred to teachers' training and professional background: a dummy for having (or not) an academic training for secondary school teaching (SISS) ${ }^{2}$, number of professional development courses attended in the current school year, years of overall professional experience and years of tenure-track status.

Model 4. In addition to model 3, some characteristics linked to inclusive teaching practice are considered: number of students with special needs who have an individualised education programme (IEP) $)^{3}$, number of students with special needs who don't have an individualised education programme, number of hours of individualised education for students with special needs per week, number of hours of non individualised education for students with special needs per week. 
Model 5. In addition to model 4, it includes some school-related variables: number of special education teachers per school, a dummy for lower or higher secondary school grade level and three dummies for levels of socio-economic disadvantage (low, medium, high).

\section{Results}

Table 1 presents descriptive statistics for the main variables used in the analysis.

Table 1

Descriptive statistics for the variables used in the analyses $(N=276)$

\begin{tabular}{lcccc}
\hline Continuous variables & Min & Max & Mean & SD \\
\hline Perceived support & 8 & 47 & 29.46 & 7.62 \\
Emotional Exhaustion & 0 & 44 & 14.49 & 9.45 \\
Depersonalisation & 0 & 17 & 1.87 & 2.77 \\
Personal Accomplishment & 16 & 48 & 37.95 & 6.99 \\
Professional development courses & 0 & 1 & 0.29 & 0.45 \\
Years of overall professional experience & 1 & 35 & 17.64 & 7.99 \\
Years of tenure-track status & 1 & 24 & 6.42 & 4.77 \\
SEN students with Individualised Education & 0 & 6 & 2.13 & 1.36 \\
SEN students without Individualised Education & 0 & 12 & 1.47 & 1.61 \\
Hours with Individualised Education per week & 0 & 18 & 11.11 & 6.02 \\
Hours without Individualised Education per week & 0 & 18 & 6.66 & 5.99 \\
Number of special education teachers per school & 1 & 18 & 6.23 & 3.44 \\
\hline
\end{tabular}


130 Langher, Caputo, Ricci-The Role of Perceived Support

Table 1

Continued

\section{Categorical variables}

Gender

Male

Female

Age class

$30-44$

$45-62$

Academic training

Yes

$30 \quad 10.9$

Not

$246 \quad 89.1$

Secondary School grade level

Lower

$146 \quad 52.9$

Higher

Socio-economic disadvantage

Low

Middle

$\begin{array}{ll}70 & 25.4\end{array}$

High

The results of the one-tailed Pearson's correlations between perceived support and burnout dimensions in special education teachers (Table 2) show that perceived support is negatively correlated with emotional exhaustion and depersonalisation, while it is positively associated with personal accomplishment. However, the correlation coefficients were significant but low, thus indicating only modest associations. 
Table 2

Correlations Between Perceived Support and Burnout Dimensions

\begin{tabular}{lcc}
\hline & Pearson's correlation & p value \\
Emotional Exhaustion & -.227 & $<.001$ \\
Depersonalization & -.124 & .019 \\
Personal Accomplishment & .219 & $<.001$ \\
\hline
\end{tabular}

The results of multilevel regression analyses suggest the potential role of perceived support in reducing emotional exhaustion (Table 3) and improving personal accomplishment (Table 5) in all the regression models considered, thus confirming the robustness of previous correlations. On the contrary, the influence of perceived support on depersonalisation is no more significant when adding control variables related to teachers' training and professional background (Table 4).

Table 3

Summary of Multilevel Regression Analyses for Predicting Emotional Exhaustion by Perceived Support in Special Education Teachers (Standardized Coefficients)

\begin{tabular}{|c|c|c|c|c|c|}
\hline & Model 1 & Model 2 & Model 3 & Model 4 & Model 5 \\
\hline Constant (B) & $10.16^{* * *}$ & $9.98 * * *$ & $7.91 * *$ & $3.52 * * *$ & $3.07^{* *}$ \\
\hline Perceived support & $-3.90^{* \bullet \bullet}$ & $-3.75 * \bullet *$ & $-3.59 * * *$ & $-3.44^{* *}$ & $-3.62 * * *$ \\
\hline Male gender & & $-2.07^{\bullet}$ & $-2.19^{*}$ & $-2.23^{*}$ & $-2.46^{* *}$ \\
\hline $45-62$ age class & & 0.99 & -0.71 & -0.77 & -0.70 \\
\hline Academic training & & & -0.61 & -0.58 & -0.66 \\
\hline Professional development courses & & & -0.99 & -1.00 & -0.87 \\
\hline Years of overall professional experience & & & 0.87 & 0.93 & 1.04 \\
\hline Years of tenure-track status & & & 0.53 & 0.43 & 0.56 \\
\hline $\begin{array}{l}\text { SEN students with Individualised Education } \\
\text { Programme }\end{array}$ & & & & 0.23 & -0.01 \\
\hline
\end{tabular}




\section{Langher, Caputo, Ricci-The Role of Perceived Support}

Table 3

Continued

SEN students without Individualised

Education Programme

$0.07 \quad 0.28$

Hours with Individualised Education per

week

$-0.62-0.48$

Hours without Individualised Education per

week

$-0.78$

Number of special education teachers per

school

Secondary school grade level

Low socio-economic disadvantage (Ref:

middle)

High socio-economic disadvantage (Ref: middle)

Teacher level (variance explained)

School level (variance explained)

Administrative area level (variance

explained)

Note: "Model 1" does not include any additional control. The other regression models progressively include some controls for teachers' socio-demographic characteristics (Model 2), teachers' training and professional background (Model 3), inclusive teaching practice (Model 4) and school-related variables (Model 5).

$* p<0.05 ; * * p<0.01 ; * * * p<0.001$ 
Table 4

Summary of Multilevel Regression Analyses for Predicting Depersonalization by Perceived Support in Special Education Teachers (Standardized Coefficients)

\begin{tabular}{|c|c|c|c|c|c|}
\hline & Model I & Model 2 & Model 3 & Model 4 & Model 5 \\
\hline Constant (B) & $4.92^{*+*}$ & $4.98^{*+*}$ & $5.37^{* * *}$ & $2.40^{* *}$ & 1.33 \\
\hline Perceived support & $-2.21^{*}$ & $-2.17^{*}$ & $-2.00^{*}$ & $-2.06^{* *}$ & -1.61 \\
\hline Male gender & & 0.18 & 0.19 & 0.21 & -0.04 \\
\hline $45-62$ age class & & -0.75 & 0.10 & 0.23 & 0.50 \\
\hline Academic training & & & -0.88 & -1.00 & -0.71 \\
\hline Professional development courses & & & $-2.82^{* *}$ & $-2.79^{* *}$ & $-2.88^{* *}$ \\
\hline Years of overall professional experience & & & -0.97 & -0.89 & -0.84 \\
\hline Years of tenure-track status & & & -0.19 & -0.37 & -0.15 \\
\hline \multicolumn{6}{|l|}{ SEN students with Individualised Education } \\
\hline Programme & & & & -1.28 & -1.72 \\
\hline \multicolumn{6}{|l|}{ SEN students without Individualised Education } \\
\hline Programme & & & & 1.52 & 1.63 \\
\hline Hours with Individualised Education per week & & & & -0.22 & 0.00 \\
\hline \multicolumn{6}{|l|}{ Hours without Individualised Education per } \\
\hline week & & & & -0.55 & -0.54 \\
\hline \multicolumn{6}{|l|}{ Number of special education teachers per } \\
\hline school & & & & & 0.23 \\
\hline Secondary school grade level & & & & & $2.18^{*}$ \\
\hline \multicolumn{6}{|l|}{ Low socio-economic disadvantage (Ref: } \\
\hline middle) & & & & & 0.81 \\
\hline \multicolumn{6}{|l|}{ High socio-economic disadvantage (Ref: } \\
\hline middle) & & & & & 1.74 \\
\hline Teacher level (variance explained) & $94.39 \%$ & $94,72 \%$ & $90.34 \%$ & $94.90 \%$ & $99.54 \%$ \\
\hline School level (variance explained) & $4.09 \%$ & $3,61 \%$ & $8.13 \%$ & $3.03 \%$ & $0 \%$ \\
\hline Administrative area level (variance explained) & $1.51 \%$ & $1,68 \%$ & $1.53 \%$ & $2.07 \%$ & $0.56 \%$ \\
\hline
\end{tabular}

Note: "Model 1" does not include any additional control. The other regression models progressively include some controls for teachers' socio-demographic 


\section{Langher, Caputo, Ricci - The Role of Perceived Support}

characteristics (Model 2), teachers' training and professional background (Model 3), inclusive teaching practice (Model 4) and school-related variables (Model 5).

$* p<0.05$; ** $p<0.01$; *** $p<0.001$

Table 5

Summary of Multilevel Regression Analyses for Predicting Personal Accomplishment by Perceived Support in Special Education Teachers (standardised coefficients)

\begin{tabular}{|c|c|c|c|c|c|}
\hline & Model I & Model 2 & Model 3 & Model 4 & Model 5 \\
\hline Constant (B) & $19.53^{* * *}$ & $19.12^{* * *}$ & $15.88^{* * *}$ & $5.45^{* * *}$ & $5.44^{* * *}$ \\
\hline Perceived support & $3.72^{* * *}$ & $3.54 * * *$ & $3.46 * *$ & $3.72^{* * *}$ & $3.47^{* *}$ \\
\hline Male gender & & 1.24 & 1.27 & 1.16 & 1.09 \\
\hline $45-62$ age class & & 0.78 & 0.78 & 0.72 & 0.62 \\
\hline Academic training & & & 0.24 & 0.17 & 0.09 \\
\hline Professional development courses & & & 0.99 & 0.73 & 0.79 \\
\hline Years of overall professional experience & & & 0.45 & 0.24 & 0.28 \\
\hline Years of tenure-track status & & & -0.61 & -0.56 & -0.56 \\
\hline \multicolumn{6}{|l|}{ SEN students with Individualised Education } \\
\hline Programme & & & & -0.02 & 0.13 \\
\hline \multicolumn{6}{|l|}{ SEN students without Individualised } \\
\hline Education Programme & & & & -0.39 & -0.32 \\
\hline \multicolumn{6}{|l|}{ Hours with Individualised Education per } \\
\hline week & & & & 0.68 & 0.64 \\
\hline \multicolumn{6}{|l|}{ Hours without Individualised Education per } \\
\hline week & & & & 0.11 & 0.11 \\
\hline \multicolumn{6}{|l|}{ Number of special education teachers per } \\
\hline school & & & & & -1.11 \\
\hline Secondary school grade level & & & & & -0.17 \\
\hline \multicolumn{6}{|l|}{ Low socio-economic disadvantage (Ref: } \\
\hline middle) & & & & & -0.39 \\
\hline \multicolumn{6}{|l|}{ High socio-economic disadvantage (Ref: } \\
\hline middle) & & & & & -0.03 \\
\hline
\end{tabular}


Table 5

Continued

\begin{tabular}{lccccc}
\hline $\begin{array}{l}\text { Teacher level (variance explained) } \\
\text { School level (variance explained) }\end{array}$ & $100 \%$ & $100 \%$ & $100 \%$ & $100 \%$ & $100 \%$ \\
$\begin{array}{l}\text { Administrative area level (variance } \\
\text { explained) }\end{array}$ & $0 \%$ & $0 \%$ & $0 \%$ & $0 \%$ & $0 \%$ \\
\hline
\end{tabular}

Note: "Model 1" does not include any additional control. The other regression models progressively include some controls for teachers' socio-demographic characteristics (Model 2), teachers' training and professional background (Model 3), inclusive teaching practice (Model 4) and school-related variables (Model 5).

$* p<0.05 ; * * p<0.01 ; * * * p<0.001$

Overall, variability among teachers seems to substantially explain their emotional exhaustion (from 93\% to 97\%), depersonalisation (from 90\% to $99 \%$ ) and personal accomplishment (100\%). Instead, the effect due to unobserved school and administrative area-related characteristics is close to zero in most cases.

The significant effects of the other covariates (control variables) on burnout measures can be summarised as follows. Personal accomplishment is not affected by any significant covariate. Instead, emotional exhaustion is predicted by gender and socio-economic disadvantage of territorial area: being a female teacher and working in a school located in a poor socioeconomic context contribute to the feeling of being emotionally overextended and exhausted by one's job. Then, with regard to depersonalisation, greater professional development tends to reduce the impersonal and cynical response toward students, while working in a lower secondary school is likely to increase the risk for detached attitude.

\section{Discussion}

The aim of this study was to explore the potential role of perceived support for reducing burnout in special education teachers coming from secondary school. As confirmed by previous studies on special education teachers, our findings show that perceived support is negatively correlated with emotional 


\section{Langher, Caputo, Ricci - The Role of Perceived Support}

exhaustion (Sari, 2004) and depersonalisation (Duli, 2015), since the lack of collegial support is conceived as one the main cause for teacher burnout in special education (Hakanen et al., 2006; Jennett, Harris, \& Mesibov, 2003; Leung \& Lee, 2006; Schaufeli \& Bakker, 2004; Talmor et al., 2005). On the contrary, perceived support is positively associated with personal accomplishment (Bataineh \& Alsagheer, 2012; Billingsley et al., 2002; Gersten et al., 2001; Platsidou \& Agaliotis, 2008), because collegial collaboration and support lead to higher feeling of acceptance, job success and participation (Platsidou \& Agaliotis, 2008). However, the results of multilevel regression analyses suggest the potential role of perceived support for reducing only two burnout measures, by lowering emotional exhaustion and improving personal accomplishment, even when other controls are considered. Instead, the relationship between perceived support and depersonalisation seems to be quite controversial. Despite a modest significant correlation is detected, perceived support does not have a predictive validity for a lowered depersonalisation when adding controls related to teacher's training and professional background. In this regard, different interpretations can be made. A first aspect to be considered refers to the limitation of the self-report measure used in the present study, as revealed by low depersonalisation scored in our general sample. It is possible that, differently from emotional exhaustion and personal accomplishment, a social desirability bias may exist in reporting depersonalisation that leads teachers to respond in a socially desirable manner, thus denying their cynic attitude toward students. Another consideration concerns the psychological nature of depersonalisation, compared to the other two burnout dimensions. While emotional exhaustion and personal accomplishment are mostly associated to inner experience, respectively in terms of perceived emotional distress or self-efficacy and work satisfaction, depersonalisation refers to teachers' dysfunctional response directly enacted in the relationship with students and school environment. In this sense, we can hypothesise that when negative attitudes and behaviours toward work arise, perceived support from colleagues or school staff may be less effective for burnout reduction. Indeed, if teachers accept to live stress-related negativity, depersonalisation can become a stable adaptive strategy for coping with stress over time, that is difficult to change. 
Relevant contributions of our study can be also derived from the effects of specific covariates. Specifically, being a female teacher and working in a school located in a poor socio-economic context seem to negatively affect emotional exhaustion. These results seem to be consistent with other research findings, according to which female teachers would report higher burnout in emotional exhaustion than their male counterparts (Lau, Yuen, \& Chan, 2005; Timms, Graham, \& Caltabiano, 2006). Indeed, teaching has been traditionally considered a female dominated-job (González-Morales, Rodríguez, \& Peiró, 2010), where females feel their work as important and feel more satisfied caring and teaching children and young. In this sense, female teachers are more likely to become emotionally involved with students' needs and thus overloaded in their daily work (Tunde \& Oladipo, 2013). For what concerns the higher emotional exhaustion of teachers working within more disadvantaged areas, consistently with previous research (Ross, Romer, \& Horner, 2012), we can hypothesise that these teachers have to cope with highly demanding aspects of the school environment. Indeed, the perception of lacking psychological resources could depend on teachers' ongoing efforts to make a high-poverty school successful, because schools with difficult socio-economic conditions are also the low-performing ones, with less organisational resources and greater amount of critical problems (for example, high rate of "at risk" students or dropouts).

Besides, teacher professional development (in terms of in-service training), seems to represent an important key factor for preventing teacher depersonalisation, as revealed by our study results. Indeed, previous studies demonstrated that teachers' attitudes towards professional development were negatively related with depersonalisation (Özer \& Beycioglu, 2010), because professional development represents a key factor preventing teacher occupational stress and promoting job control (Kwakman, 2001). However, because the nature of our study is correlational, we can also consider that burned out teachers are likely to attend professional development with less frequency than the enthusiastic and motivated teacher, who seeks ideas for innovative instruction. In relation to higher depersonalisation in teachers coming from lower secondary schools (6-9 grade), a study by Anderson and Iwanicki (1984) noted a curvilinear relationship between grade level and 


\section{Langher, Caputo, Ricci-The Role of Perceived Support}

burnout, with lower (middle) secondary school teachers displaying more burnout than did elementary and higher secondary school teachers. This result is confirmed by other studies (Shoho, 2002), according to which middle school teachers were found to report the strongest feelings of depersonalisation, as well as less professional commitment, motivation and satisfaction with teaching, than either elementary or higher secondary school teachers. We can hypothesise that, at this school level, teachers have to face stressful work conditions linked to the transition from primary to secondary education. Indeed, compared to elementary school, middle school is characterised by greater heterogeneity of classes, imposition of measurable goal-achievement standards, higher discipline problems. In addition, these teachers have to care and teach young children, not yet adolescents, thus they could still feel responsible for satisfying both the emotional and physical needs of students. In this perspective, depersonalisation may be considered as a defence strategy aimed at not being emotionally involved with students' problems, because lower secondary school teachers are more required to respond in a caring and sensitive way, compared to higher secondary school teachers.

\section{Conclusions}

The present study overall suggests the relevance of perceived support in reducing special education teachers' burnout also in the Italian context, where students with special education needs are fully included in mainstream education and collaboration with regular teachers is a critical issue. The added-value of the study relies on providing robust evidence taking into account special education teachers' environments and potential context-related effects by multilevel modelling. The findings highlight the need for improving supportive environments for burnout prevention, especially in at risk situations such as for schools from socio-economically disadvantaged areas and female teachers (for emotional exhaustion) and for lower secondary schools (for depersonalisation). Besides, promoting professional development may represent a key-factor for lowering feelings of depersonalisation by supporting teachers' perceived competence in the classroom and leading them to appreciate and value their work more (Fernet, 
Guay, Senécal, \& Austin, 2012). However, it is important that continuing professional development is not compulsory, because research in the workplace has evidenced that only teachers who show more autonomous (intrinsic motivation and identified regulation) than controlled (introjected and external regulation) motivation display greater well-being (Ryan \& Deci, 2000) and lower burnout (Fernet, Senécal, Guay, Marsh, \& Dowson, 2008).

Some limitations regarding this study need to be taken into account in order to put the findings into perspective. A limitation, that is common to many other studies, concerns the specific instrument used to assess burnout. In fact, the lack of a multi-method approach might underestimate the actual incidence of burnout, that could be measured by using also objective indicators (for example, absenteeism rate, incidents occurred at school, etc.) in order to confirm and integrate teachers' reports. However, the specific aim of this study was to explore the teachers' subjective experience concerning job-related stress. In this regard, a recommendation for further research could be to use a social desirability measure in order to control social desirability bias in self-report burnout measures, moreover in depersonalisation dimension. An interesting future development of our finding could be also to consider the variety of perceived support sources (i.e. administrative, parental, etc.) and differentiate the specific contributions of these different sources to teacher burnout. Another limitation concerns the causal relationship between perceived support and the burnout dimensions analysed. At this regard, emotional exhaustion, depersonalisation and personal accomplishment might also be considered as independent factors that can affect teachers' proneness to receive and enjoy support from colleagues or school staff. In this sense, they might in turn contribute over time to a lowered perceived support, within a downward spiral which may perpetuate burnout. However, longitudinal data would be required to disentangle the pattern of these causal effects in further research. 


\section{Langher, Caputo, Ricci - The Role of Perceived Support}

\section{Notes}

1 Each year, the regional offices of the Ministry of Education, Universities and Research (MIUR) allocate special education teachers to each school, according to the number of pupils and the typology of disabilities.

${ }^{2}$ In the Italian school system, only in 1998-1999, with the institution of the School of Primary Education (Corso di Laurea in Scienze della Formazione Primaria) and the Graduate School of Secondary School Teacher Training (Scuola di Specializzazione Interateneo per la Formazione degli Insegnanti di Scuola Secondaria, whose most popular acronymous is SSIS), all future teachers are supposed to have an academic degree.

${ }^{3}$ In Italy, depending on the type and seriousness of disability, students with special education needs can be provided with an individualized education program (an adapted curriculum which meets their specific needs) or with a program that is not differentiated from the rest of the class (a common curriculum which meets all students' needs).

\section{References}

Acanfora, L. (2002). Come logora insegnare: Il burn out degli insegnanti [How stressful teaching is: Teacher burnout]. Roma: Edizioni Magi. Al-Shammari, Z. (2006). Special education teachers' attitudes toward autistic students in the autism school in the state of Kuwait: a case study. Journal of Instructional Psychology, 33(3), 170-178.

Anderson, M. B. G., \& Iwanicki, E. F. (1984). Teacher motivation and its relationship to burnout. Educational Administration Quarterly, 20(2), 109-132. doi: 10.1177/0013161X84020002007

Avramidis, E., \& Norwich, B. (2002). Teachers' attitudes towards integration/inclusion: A review of the literature. European Journal of Special Needs Education, 17, 129-147. doi:

10.1080/08856250210129056

Bataineh, O., \& Alsagheer, A. (2012). An Investigation of Social Support and Burnout Among Special Education Teachers in the United Arab Emirates. International Journal of Special Education, 27(2), 5-13. Retrieved from http://www.internationaljournalofspecialeducation.com/articles.cfm?y $=2012 \& v=27 \& n=2$

Billingsley, B., Carlson, E., \& Klein, S. (2002). Working conditions and induction support of early career special educators. Exceptional Children, 70, 333-347. 
Bronfenbrenner, U. (1977). Toward an experimental ecology of human development. American Psychologist, 32, 513-531.

Brownell, M. T., \& Smith, S. W. (1993). Understanding special education teacher attrition: A conceptual model and implications for teacher educators. Teacher Education and Special Education, 16, 270-282. doi:10.1177/088840649301600309

Brunsting, N. C., Sreckovic, M. A., \& Lane, K. L. (2014). Special education teacher burnout: A synthesis of research from 1979 to 2013.

Education and Treatment. 37(4), 681-712. doi: 10.1353/etc.2014.0032

Cancio, E. J., Albrecht, S. F., \& Johns, B. H. (2013). Defining administrative support and its relationship to the attrition of teachers of students with emotional and behavioral disorders. Education and Treatment of Children, 36(4), 71-94. doi: 10.1353/etc.2013.0035

Caputo, A., \& Langher, V. (2015). Validation of the Collaboration and Support for Inclusive Teaching (CSIT) scale in special education teachers. Journal of Psychoeducational Assessment, 33(3) 210-222. doi: 10.1177/0734282914548335

Carli., R., \& Paniccia, R. M. (2003). Analisi della domanda: Teoria e tecnica dell intervento in psicologia clinica [Analysis of demand. Theory and technique of the intervention in clinical psychology]. Bologna: Il Mulino.

Dillon, S. (2007, August 27). With turnover high, schools fight for teachers. The New York Times. Retrieved from http://nytimes. Com

Duli, S. (2015). Proactive Coping and Professional Burnout in Special Education. Academic Journal of Interdisciplinary Studies, 4(3), 18-23. doi: 10.5901/ajis.2015.v4n3s1p18

Evers, W. J. G., Brouwers, A., \& Tomic, W. (2002). Burnout and selfefficacy: A study on teachers' beliefs when implementing an innovative educational system in the Netherlands. British Journal of Educational Psychology, 72(2), 227-243. doi:

$10.1348 / 000709902158865$

Fernet, C., Guay, F., Senécal, C. \& Austin, S. (2012). Predicting intraindividual changes in teacher burnout: The role of perceived school environment and motivational factors. Teaching and Teacher Education, 28(4), 514-525. doi: 10.1016/j.tate.2011.11.013 


\section{Langher, Caputo, Ricci - The Role of Perceived Support}

Fernet, C., Senécal, C., Guay, F., Marsh, H., \& Dowson, M. (2008). The Work Tasks Motivation Scale for Teachers (WTMST). Journal of Career Assessment, 16(2), 256-279. doi: 10.1177/1069072707305764

Friedman, I. (2000). Burnout: shattered dreams of impeccable professional performance. Journal of Clinical Psychology, 56, 595-606. doi: 10.1002/(SICI)1097-4679(200005)56:5<595::AID-JCLP2>3.0.CO;2-

Q

Futernick, K. (2007). A possible dream: Retaining California teachers so all students learn. Sacramento: The Center for Teacher Quality, California State University.

Gersten, R., Keating, T., Yovanoff, P., \& Harniss, M. K. (2001). Working in special education: Factors that enhance special educators' intent to stay. Exceptional Children, 67(4), 549-567.

González-Morales, M. G., Rodríguez, I., \& Peiró, J. M. (2010). A longitudinal study of coping and gender in a female-dominated occupation: Predicting teachers' burnout. Journal of Occupational Health Psychology, 15(1), 29-44. doi: 10.1037/a0018232

Hakanen, J. J., Bakker, A. B., \& Schaufeli,W. B. (2006). Burnout and work engagement among teachers. Journal of School Psychology, 43, 495513. doi: 10.1016/j.jsp.2005.11.001

Hinds, E., Jones, L. B., Gau, J. M., Forrester, K. K., \& Biglan, A. (2015). Teacher Distress and the Role of Experiential Avoidance. Psychology in the Schools, 52(3), 284-297. doi: 10.1002/pits.2015.52.issue-3

Honawar, V. (2006). Alternative routes for special education teachers relieving shortages worsened by NCLB. Education Week, 25(34), 116.

Hox, J. (2002). Multilevel analysis. Techniques and applications. Mahwah, NJ: Lawrence Erlbaum.

ISTAT (2014). L'integrazione degli alunni con disabilità nelle scuole primarie e secondarie di primo grado statali e non statali [Inclusion of students with disabilities in primary and lower secodary public and nonpublic schools]. Retrieved from http://www.istat.it

Jennett, H. K., Harris, S. L., \& Mesibov, G. B. (2003). Commitment to philosophy, teacher efficacy, and burnout among teachers of children 
with autism. Journal of Autism and Developmental Disorders, 33, 583-593. doi: 10.1023/B:JADD.0000005996.19417.57

Kaff, M. S. (2004). Multitasking is multiaxing: Why special educators are leaving the field. Preventing School Failure, 48(2), 10-17.

Kourkoutas, E., Langher,V., Vitalaki, E., \& Ricci, M. E. (2015). Working with Parents to Support Their Disabled Children's Social and School Inclusion: An Exploratory Counseling Study. Journal of Infant, Child, and Adolescent Psychotherapy, 14(2), 143-157.

doi:10.1080.15289168.2015.1014990

Kwakman, K. (2001). Work stress and workbased learning in secondary education: testing the Karasek model. Human Resource Development International, 4(4), 487-501.

Langher, V., Caputo, A., Ajdinski, G., Ricci, M.E., \& Karovska, A. (2015).

Cultural Models of Special Education in Macedonia: Towards a Systemic and Integrative Perspective. In S. Bowman (Ed.), Special Education: Developments, Teaching Strategies and Parental Involvement (pp. 41-64). New York, NY: Nova Science Publishers. Langher, V., Caputo, A., Ricci, M. E., \& Ajdinski, G. (2014). Regular teachers' representation of school inclusion in Macedonia: A multivariate study. Rivista di Psicologia Clinica, 2, 108-121. doi: 10.14645/RPC.2014.2.487

Langher, V., Ricci, M. E., Propersi, F., Glumbic, N., Caputo, A., \& Groterath A. (2015). Inclusion in the time of cholera. In U. Brizay, R. Lutz, \& F. Ross (Eds.), Sozialarbeit des Südens, Bd. 5 - Zugang zum Gesundheitswesen und Gesundheitspolitik [Social work in the South, Vol. 5 - Access to Health Care Services and Health Policy] (pp.323338 ). Oldenburg, Germany: Paulo Freire Verlag.

Langher, V., Ricci, M. E., Propersi, F., Glumbic, N., \& Caputo, A. (2016).

Inclusion in Mozambique: a case study on a cooperative learning intervention. Cultura Y Educaciòn: Culture and Education, 28(1) 4271. doi: 10.1080/11356405.2015.1120447

Langher, V., Ricci, M. E., Reversi, S., \& Citarelli, G. (2010). Disabled students and the quality of relationships within the class. Procedia Social and Behavioral Sciences, 5, 2295-2299. doi:

10.1016/j.sbspro.2010.07.452 


\section{Langher, Caputo, Ricci - The Role of Perceived Support}

Lau, P. S., Yuen, M. T., \& Chan, R. M. (2005). Do demographic characteristics make a difference among Hong Kong secondary school teachers? Social Indicators Research, 71(1-3), 491-516. doi:

10.1007/s11205-004-8033-Z

Leung, D. Y. P., \& Lee, W. W. S. (2006). Predicting intention to quit among Chinese teachers: differential predictability of the components of burnout. Anxiety, Stress \& Coping. An International Journal, 19, 129141.

Lindmeier, B. (2013). Professionelles Handeln im Förderschwerpunkt geistige Entwicklung [Professional Acting in the Area of Mental Disability]. In K.-E. Ackermann, O. Musenberg \& J. Riegert (Eds.), Geistigbehindertenpädagogik!? Disziplin - Profession - Inklusion [Education in the Area of Mental Disability!? Discipline - Profession - Inclusion] (pp. 291-313). Oberhausen: Athena.

Maslach, C., \& Jackson, S. E. (1986). Maslach Burnout Inventory manual.

Palo Alto, CA: Consulting Psychologists Press.

Norwich, B. (2013). Addressing Tensions and Dilemmas in Inclusive

Education: Living with Uncertainty. London: Routledge

OECD (2008). Education at a glance. OECD: Paris.

Özer, N., \& Beycioglu, K. (2010). The relationship between teacher professional development and burnout. Procedia-Social and Behavioral Sciences, 2(2), 4928-4932. doi:

10.1016/j.sbspro.2010.03.797

Pepe, A., \& Addimando, L. (2013). Comparison of Occupational Stress in Response to Challenging Behaviours between General and Special Education Primary Teachers in Northern Italy. International Journal of Special Education, 13(1), 11-23.

Platsidou, M., \& Agaliotis, I. (2008). Burnout, Job Satisfaction and Instructional Assignment-related Sources of Stress in Greek Special Education Teachers. International Journal of Disability, Development and Education, 55(1), 61-76. doi: 10.1080/10349120701654613

Prather-Jones, B. (2011). Flow school administrators influence the retention of teachers of students with emotional and behavioral disorders. The Clearing House, 84, 1-8. doi: 10.1080/00098655.2010.489387. 
Reeve, P.T., \& Hallahan, D.P. (1994). Practical questions about the collaboration between general and special educators. Focus on Exceptional Children, 26(7), 1-11.

Reversi, S., Langher, V., Crisafulli, V., \& Ferri, R. (2007). The quality of the disabled students' school integration: A research experience in the Italian state school system. School psychology international, 28(4), 403-418.

Ryan, R. M., \& Deci, E. L. (2000). Self-determination theory and the facilitation of intrinsic motivation, social development, and wellbeing. American Psychologist, 55(1), 68-78. doi: 10.1037/0003066X.55.1.68

Ross, S., Romer, N. \& Horner, R. (2012). Teacher well-being and the implementation of school-wide positive behavior interventions and supports. Journal of Positive Behavior Interventions, 14(2), 118-128. doi: 10.1177/1098300711413820

Sari, H. (2004). An analysis of burnout and job satisfaction among Turkish special school headmasters and teachers, and the factors affecting their burnout and job satisfaction. Educational Studies, 30(3), 291306. doi: 10.1080/0305569042000224233

Schaufeli, W. B., \& Bakker, A. D. B. (2004). Job demands, job resources, and their relationship with burnout and engagement: a multi-sample study. Journal of Organizational Behavior, 25, 293-315. doi: $10.1002 /$ job. 248

Schlichte, J., Yssel, N., \& Merbler, J. (2005). Pathways to burnout: Case studies in teacher isolation and alienation. Preventing School Failure, 50, 35-40. doi: 10.3200/PSFL.50.1.35-40

Shoho, A. R. (2002). A comparison of burnout between general and special education teachers. In G. S. Gates \& M. Wolverton (Eds.), Toward Wellness: Prevention, coping, and stress (pp. 144-158). Greenwich, CT: Information Age Publishing

Sirigatti, S., \& Stefanile, C. (1993). Adattamento e taratura per l'Italia [Italian Adaptation]. In C. Maslach \& S. Jackson (Eds.), MBI Maslach Burnout Inventory: Manuale [MBI Maslach Burnout Inventory: Manual] (pp. 33-42). Firenze: Organizzazioni Speciali. 
Stoesz, B. M., Shooshtari, S., Montgomery, J., Martin, T., Heinrichs, D. J., \& Douglas , J. (2016). Reduce, manage or cope: a review of strategies for training school staff to address challenging behaviours displayed by students with intellectual/developmental disabilities. Journal of Research in Special Educational Needs, 16(3), 199-224. doi: 10.1111/1471-3802.12074.

Talmor, R., Reiter, S., \& Feigin, N. (2005). Factors relating to regular education teacher burnout in inclusive education. European Journal of Special Needs Education, 20(2), 215-229. doi:

\section{$10.1080 / 08856250500055735$}

Timms, C., Graham, D., \& Caltabiano, M. (2006). Gender implication of perceptions of trustworthiness of school administration and teacher burnout/job stress. Australian Journal of Social Issues, 41(3), 343358.

Tunde, A. O., \& Oladipo, O. (2013). Influence of Personality and SelfEsteem on Teachers' Proness to Burnout Syndrome in Lagos Metropolis. American Journal of Applied Psychology, 1(1), 7-13. doi: 10.12691/ajap-1-1-2

Villa, R.A., \& Thousand, J.S. (1994). One divided by two or more: Redefining the role of a cooperative education team. In J.S. Thousand, R.A. Villa, \& A.I. Nevin (Eds.), Creativity and collaborative learning: A practical guide to empowering students and teachers (pp. 79-101), Baltimore: Paul H. Brookes.

Zabel, R. H., \& Zabel, M. K. (2002). Burnout among special education teachers and perceptions of support. Journal of Education Leadership, 15(2), 27-33. 
Dr. Viviana Langher is a Professor of Clinical Psychology at the Department of Dynamic and Clinical Psychology at Sapienza University of Rome.

Dr. Andrea Caputo is a $\mathrm{PhD}$ student at the Department of Dynamic and Clinical Psychology at Sapienza University of Rome.

Dr. Maria Elisabetta Ricci is a Lecturer of Clinical at the Department of Dynamic and Clinical Psychology at Sapienza University of Rome.

Contact Address: Via degli Apuli, 1, 00185 Rome, Italy. Email: viviana.langher@uniroma1.it 